\title{
Pedagogical practice for science teaching during the COVID-19 pandemic in the view of Biological Sciences undergraduate students from a public Brazilian university ${ }^{1}$
}

\author{
Prática pedagógica para o ensino de ciências durante a pandemia da COVID-19 na visão de \\ estudantes de Licenciatura em Ciências Biológicas de uma universidade pública brasileira \\ Práctica pedagógica para la enseñanza de las ciencias durante la pandemia de COVID-19 en la \\ visión de los estudiantes de graduación en Ciencias Biológicas de una universidad pública brasileña
}

Received: 01/26/2022 | Reviewed: 02/04/2022 | Accept: 02/10/2022 | Published: 02/16/2022

\author{
Deyla Paula de Oliveira \\ ORCID: https://orcid.org/0000-0003-2929-8288 \\ University of Pernambuco, Brazil \\ E-mail: deylaoliver@gmail.com \\ Ayslane Barros dos Santos \\ ORCID: https://orcid.org/0000-0001-6324-7033 \\ University of Pernambuco, Brazil \\ E-mail: ayslane.barros@upe.br \\ Gustavo Cunha de Araújo \\ ORCID: https://orcid.org/0000-0002-1996-5959 \\ Federal University of Northern Tocantins, Brazil \\ E-mail: gustavocaraujo@yahoo.com.br
}

\begin{abstract}
Due to the pandemic of COVID-19 and the need for social isolation, following World Health Organization guidelines, teaching activities began to be offered remotely in educational institutions. This study aimed to report the opinion of Biological Sciences undergraduate students from a public Brazilian university about the discipline Pedagogical Practice, developed in the remote format, during the COVID-19 pandemic. This is a qualitative-quantitative study, of the opinion poll type, with 17 students as public. The students' opinion was collected through an evaluative activity applied at the end of the course Pedagogical Practice online through Google Forms in the year 2021. Among some results, the students mentioned the decrease in the quality of the subject taught remotely, problems and difficulties in accessing the internet, with slow or unstable connections; the absence of face-to-face practical classes that makes it impossible to contact and socialize with teachers and classmates, and the overload and difficult concentration during this period.
\end{abstract}

Keywords: Teaching; Sciences; Biology; Remote learning; Pedagogical practice.

\section{Resumo}

Devido à pandemia da COVID-19 e à necessidade de isolamento social, seguindo as diretrizes da Organização Mundial da Saúde, atividades de ensino começaram a ser ofertadas de forma remota em instituições educacionais. Este estudo objetivou relatar a opinião de estudantes de Licenciatura em Ciências Biológicas de uma universidade pública brasileira acerca da disciplina Prática Pedagógica, desenvolvida no formato remoto, durante a pandemia da COVID-19. Este é um estudo de caráter quali-quantitativo, do tipo pesquisa de opinião, tendo como público 17 estudantes. A opinião dos estudantes foi coletada por meio de uma atividade avaliativa aplicada ao final da disciplina Prática Pedagógica de maneira on-line por meio do Google Formulário no ano de 2021. Dentre alguns resultados, os estudantes mencionaram a diminuição da qualidade da disciplina ministrada de forma remota, problemas e dificuldades no acesso à internet, com conexões lentas ou instáveis; a ausência de aulas práticas presenciais que inviabiliza o contato e o convívio com os professores e colegas de turma e a sobrecarga e a difícil concentração nesse período.

Palavras-chave: Ensino; Ciências; Biologia; Ensino remoto; Prática pedagógica.

\section{Resumen}

Debido a la pandemia del COVID-19 y la necesidad del aislamiento social, siguiendo los lineamientos de la Organización Mundial de la Salud, se comenzaron a ofrecer actividades docentes a distancia en las instituciones

\footnotetext{
${ }^{1}$ Texto traduzido por: Silvia Iacovacci. Graduada em: Secretariado Bilíngue e Tradução de Inglês Comercial - Instituto Schumann - Roma, Itália. E-mail: siacovacci@gmail.com.
} 
educativas. Este estudio tuvo como objetivo informar la opinión de estudiantes de graduación en Ciencias Biológicas de una universidad pública brasileña sobre la disciplina Práctica Pedagógica, desarrollada en formato remoto, durante la pandemia de COVID-19. Se trata de un estudio cualitativo-cuantitativo, del tipo investigación de opinión, con 17 estudiantes como audiencia. Se recogió la opinión de los estudiantes a través de una actividad evaluativa aplicada al término de la disciplina Práctica Pedagógica en línea a través de Google Forms en el año 2021. Entre algunos resultados, los estudiantes mencionaron la disminución de la calidad de la disciplina impartida en forma remota, problemas y dificultades para acceder a internet, con conexiones lentas o inestables; la ausencia de clases prácticas presenciales, que hace inviable el contacto y la interacción con profesores y compañeros, y la sobrecarga y dificultad de concentración durante este periodo.

Palabras clave: Enseñanza; Ciencias; Biología; Enseñanza remota; Práctica pedagógica.

\section{Introduction}

In Brazil, traditionally, undergraduate curricula have been conceived as mere appendices to in the articulation between theory and practice, in which pedagogical subjects are presented as a final complement, disconnected from the specific content subjects. This curricular fragmentation is related to the very history of undergraduate education in Brazil, since the promulgation of Decree Law no. 1.190, dated April 4, 1939 (Brazil, 1939).

In the last twenty years, discussions related to teacher education (both initial and continuing education) very influenced by this Decree, have been taking place in an intense manner, and it is a consensus among researchers that some reformulations should be carried out in order to meet the manifest expectations of education. In this way, it is necessary to think of teacher training as moments in a continuous process of building a qualified teaching practice and of affirming teachers' identity, professionalism, and professionalization. In addition to knowing the content to be taught and mastering the teaching methodologies, the teacher needs to be aware of the real needs of students and, especially, in his role in the formation of these individuals (Kafer et al., 2017).

However, with the pandemic of the new coronavirus (SARS-CoV-2), COVID-19, which significantly changed people's lives, since it was necessary to comply with a series of measures to prevent the spread of this virus causing numerous cases and deaths in the Brazilian public and private health network (Menezes, 2021), it was necessary to maintain social distance, hand hygiene, use of masks, remote work and teaching, among others, causing a significant change in teaching and learning in the educational context (Castaman \& Rodrigues, 2020).

Consequently, this change in teaching also affected the pedagogical practices developed in undergraduate courses, since teachers had to reorganize themselves to learn how to use new technological tools to teach the contents of their curricular subjects (Menezes, 2021). With this, teaching activities, both in Basic and Higher Education in Brazil, since March 2020, have been carried out remotely from online platforms, such as Google Meet (Roig-Vila et al., 2021) and Google Classroom (Silva, 2021), for example.

In the cycle under discussion, the pedagogical practices developed in undergraduate courses, especially in Biological Sciences, at this time of the COVID-19 pandemic, needed to undergo reformulations, because working with new teaching methodologies provides students with significant gains both as students and after graduation. Thus, it is understood in this research that the pedagogical practices developed in undergraduate courses should be based on the initial and continuing education of teachers in a contextualized manner, in addition to greater dynamism in the pedagogical process, since it is in undergraduate courses that students have contact with the specificities of practical and theoretical subjects that are the foundation of their learning for teaching.

Since studies about pedagogical practices developed via home office in Biological Sciences courses during the pandemic of the new coronavirus (SARS-CoV-2) are scarce in the academic literature, this study aimed to report the opinion of Biological Sciences undergraduate students from a public Brazilian university about the discipline Pedagogical Practice, developed from the Emergency Remote Learning (ERE), during the COVID-19 pandemic. 


\section{Material and Methods}

This is a quali-quantitative study, of the opinion survey type (Bogdan \& Biklen, 2010), with 17 students of a Biological Sciences undergraduate students from a public Brazilian university. Regarding qualitative research, Minayo (2001) points out that it is characterized by the understanding of something accompanied by doubt despite theories to prove a particular object of study. As for quantitative research, for Fonseca (2002), this approach uses mathematical language to describe the causes of a phenomenon, the relationships between variables, etc. Finally, opinion research refers to a methodological instrument that aims to learn about the reality, behaviors, and opinions of a social group (Weber \& Pérsigo, 2017).

The students' opinion was collected through an evaluative activity applied at the end of the discipline Pedagogical Practice online through Google Forms in the year 2021. The questions were about the main problems and limitations of the teaching-learning of the subject from remote teaching; which methodologies and didactic resources allowed for more significant learning; what contribution the reading and presentation of articles made to learning; which methodologies and didactic resources would be used in the teaching process, and what the importance of the subject and the subjects covered was.

Since it is an opinion survey, according to Resolution no. 466, of December 12, 2012 (Brazil, 2012) and Resolution no. 510, of April 7.2016 (Brazil, 2016), it was not necessary to submit the project for approval by the Ethics Committee on Research with Human Beings - CEP. In addition, to preserve the anonymity of the students of the subject, they were identified by codes, such as, for example: E1, E2, and so on.

The data returning from the activity were tabulated and analyzed descriptively, with exposure of quantitative and qualitative variables, in the form of absolute and relative frequency and through content analysis. Content analysis is commonly used to represent the treatment of data from a qualitative or quantitative research in education, since it describes the contents of the participants' answers, and allows the authors to make inferences about the knowledge obtained in such statements (Bardin, 2011). After the content analysis, the categorization of the information obtained from the participants was performed (Moraes, 1999).

\section{Results and Discussion}

At the end of the Pedagogical Practice discipline at the Brazilian public university that was the focus of this study, the students were asked to give their opinions about the main problems and limitations of the teaching-learning of the subject using remote teaching. Among the mentions were the issue of time, which in remote teaching ends up having to be shorter, with synchronous classes lasting only $1 \mathrm{~h} 30 \mathrm{~min}$ to $2 \mathrm{~h}$; the decrease in the quality of the subject taught remotely; limitations and/or absence of internet and the fact that it is not possible to have face-to-face practical classes, and thus lose contact and conviviality with teachers and classmates. The students also mentioned the overload that remote teaching ended up causing, due to the excess of activities of all subjects, because as the workload of synchronous classes is reduced, the teacher has to perform more activities and post extra materials asynchronously, to be able to meet the total workload of the discipline, and also the difficult concentration that this moment has caused, as can be observed in the statements of nine students:

In my opinion, the courses offered remotely do not have the same quality as the face-to-face ones (E1).

Not being possible to have face-to-face practice (E2).

The contact person to person is very important in the learning process, because there is a greater interaction (E3).

Maybe do some research in a school, try to see the biggest complaints of the students. For example, try to understand the school dropouts and how to reduce them (E4). 
Sometimes my connection was bad and this made me miss some of the teacher's explanations; I was overloaded with too many activities in other discipline, this gave me less time to perform the activities in this discipline and I did not do them with due excellence; the decrease of interaction with the teacher and with my classmates because of the remote teaching, this interaction would be much greater if we were in person (E5).

Internet connection, difficult concentration, due to factors external to the class (E6).

In my case, it was the internet that was not always good enough to stay in class (E7).

Many discipline passing material asynchronously to compensate for the workload, which accumulated many activities and overloaded the students (E8).

One of the main problems was the amount of activity in a short time, because this remote teaching makes it very difficult, it is complicated several activities, both personal and academic, because it messes with the psychological (E9).

The students' speeches are important, because they reveal that remote teaching, although it is the most appropriate in times of pandemic, since it is necessary to comply with health protocols, aiming to avoid crowds and maintain social distance, according to WHO recommendations, does not present the same quality of face-to-face teaching. Moreover, it was revealed in their statements that there was a significant overload of activities, which can affect their emotional health, and even cause stress, fatigue, and emotional exhaustion, not only in students, but also in teachers (Langin, 2021).

At this time, when schools and universities had to close due to the pandemic of COVID-19 and aiming to minimize the spread of the new coronavirus (SARS-CoV-2), the Digital Information and Communication Technologies (ICT) were primordial for the maintenance of distance learning classes in teaching institutions of Basic and Higher Education in Brazil. However, another fact that needs to be highlighted in this study, concerns the lack of quality of the internet, since many students reported that they had difficulties with the connection during the remote classes, which also impairs the teaching and learning process of these students.

Thus, the difficulties mentioned by students deserve attention, as there are studies that have indicated that non-face-toface teaching can provoke in student's feelings of loneliness (Dosea, et al., 2020), as well as making evident the lack of technical mastery for the use of digital technologies (Emanuelli, 2020).

In order to discuss the opportunities and challenges of remote learning, from the point of view of students of an undergraduate course in the area of Exact Sciences, Santos et al. (2020), detected that among the challenges mentioned, were the issue of non-accessibility or even the poor quality of the internet and also the difficulty of students to maintain attention during remote classes, mentions similar to those found in this study.

Despite the reports of some problems and limitations in the teaching-learning of the discipline Pedagogical Practice from remote teaching, the students mentioned that some methodologies and didactic resources used in the teaching of the subject allowed them to learn the contents in a meaningful way. Among them, reading and reflecting on scientific articles was the methodology most mentioned by the students, with $32.3 \%(n=10)$ of the mentions, followed by seminars, debates and lectures, with $29 \%(\mathrm{n}=9)$ of the mentions (Table 1$)$. 
Table 1: Categories of responses obtained on the mentions of the methodologies and teaching resources that allowed, in the students' opinion, greater meaningful learning.

\begin{tabular}{l|c|c}
\hline \multicolumn{1}{c|}{ Categories } & $\mathbf{N}^{\circ}$ & \% \\
\hline Reading/reflection of scientific articles & 10 & 32.3 \\
Seminars/discussions/lectures & 9 & 29.0 \\
Lectures/books & 5 & 16.1 \\
Films/videos & 4 & 12.9 \\
Research resources/proposed activities & 3 & 9.7 \\
\hline \multicolumn{1}{c|}{ TOTAL } & 31 & 100 \\
\hline
\end{tabular}

Source: Prepared by the authors (2022).

It is known that in order to achieve meaningful learning, i.e., "... that in which ideas expressed symbolically interact in a substantive and non-arbitrary way with what the learner already knows... that the interaction is not with any previous idea, but with some specifically relevant knowledge already existing in the cognitive structure of the subject who learns" (Moreira, 2012, p. 30), it is necessary that the teacher adopts diversified teaching methodologies and resources, which is clear even in the speech of two students:

All the resources that were used had many contributions, because from an article, for example, seminars, activities and blogs were worked. So all the resources interacted with each other and helped the growth of learning (E1).

Through the activities, the seminars, and the lecture class as well. In general, the learning was very significant in all the proposed activities (E2).

For these students, reading scientific articles allowed a greater theoretical deepening, a better assimilation and reflection of the themes of teaching-learning of Science and Biology addressed in the articles, as well as allowed reflection and conduct of classes for students of Basic Education, as is clear in the speech of a student: "I learned a lot. It made me reflect about the way I want to teach my students" (E1).

Moreover, this methodology allowed students to have a more scientific view of the themes worked on in class, to understand/know in a deeper way the structure of a scientific article and also instigated the search for articles on other themes, as can be detected in the statements of five students:

Both reading and presentation of articles contributed, but especially the presentation, because in addition to my interpretation and lived experiences, my teammates also brought their contributions and thus I could learn more from the different points of view. Learning through the study of articles is enriching, because besides learning about the themes, we also learn to have a more scientific view, and this is a great tool that is also little used by the teachers of the course, unfortunately (E1).

Reading scientific articles helped me both in understanding the results of a research study and in writing an article. It was an important source that contributed a lot to my knowledge. In short, it made all the difference to my learning (E2).

Having contact with scientific articles is essential in teacher training. Particularly, I learned a lot, because we learned to debate, to expose our point of view. It allowed a greater reflection on the subjects (E3).

As I am not in the habit of reading scientific articles, if it is mandatory in the discipline, I read them. So, here I already have an addition of a type of reading that I don't enjoy much. I also realized that not every scientific article is boring to read. And the presentation that I did in the chat style brings an element of surprise because it is not something rehearsed. We all have a baggage of knowledge; it was enough to follow a certain script for the ideas to be explained by the members (E4). 
The scientific articles made me open my eyes to various situations that a classroom can have. So, they were of great value for my understanding about the things that happened and also made me think about solutions and, when I am a teacher, how I will be able to solve and reduce the impacts for my students. After the support material, I was looking more and more to read scientific articles to have more knowledge (E5).

The presentations of scientific articles, through seminars, also had great contributions to learning, and according to $29 \%(n=9)$ of the students, through this methodology, it was possible to learn more from the different points of view on the themes that were being presented and debated, and it was also detected that in some way we all bring a baggage of knowledge and that this knowledge can be improved and/or reformulated through debates, where I learn from the other's opinion and thus, I can formulate my own world view.

In this way, we can see that reflective practice can help the teacher and the student to respond to uncertain and fluctuating situations, providing conditions to create solutions and new ways of acting in the world, as long as it works with issues close to the students' reality, based on scientific studies. It is believed, however, that reflection alone contributes little, and the important thing in this process is to know what to reflect on and how this process occurs. That is, it is important to understand in order to understand, and after expressing oneself, as is advocated by significant learning, since this perspective considers prior knowledge relevant so that the individual can learn and become aware of his reality (Moreira, 2012).

Seminars and debates, particularly in remote teaching, also allow classes to be less monotonous, with the teacher presenting/teaching and the students just listening, because in many cases, what we observe in this teaching modality, are teachers talking alone, with their camera on, and students quiet, with their cameras off. Thus, working with academic texts, in this case, scientific articles, allows and encourages student participation in remote classes, which is also in line with what is expected in teaching-learning: that teachers are facilitators and not holders of knowledge, and students as central to this process, moving from a vertical to a horizontal relationship in the production of knowledge (Dosea et al., 2020).

Although, in general, it can be detected that the students were satisfied with the way the discipline was conducted and with the methodologies and didactic resources used in remote teaching, we cannot fail to mention that remote teaching cannot be, in a way, compared to face-to-face teaching, especially in a discipline of Pedagogical Practice, because, as the name implies, the discipline brings in itself the need to associate theory with practice. Thus, 64.7\% $(n=11)$ of the students reported that they would have liked to have had the opportunity to study the discipline using other didactic and pedagogical methods, and $53.4 \%(\mathrm{n}=8)$ of the students reported that they would have liked to have had more classes and practical activities (Table 2), preferably face-to-face, as is clear in the speech of one student:

I would like to practice everything in class. To have that own experience to put the "hands-on" of what I was learning. I think it would be good (E1).

The above quote is revealing, because students miss the teacher-student and student-student interaction, and still according to them, having face-to-face classes are important to improve their performance in the subjects. However, it is important to highlight that in this case, teachers can choose to use different didactic resources, to make up a little for this absence of face-to-face classes and provide better learning to students (Feitosa et al., 2020). 
Table 2: Categories of answers obtained about the mentions of other didactic and pedagogical methods to be used in the teaching-learning of the discipline Pedagogical Practice.

\begin{tabular}{|c|c|c|}
\hline Categories & $\mathbf{N}^{\circ}$ & $\%$ \\
\hline Practical classes/activities & 8 & 53.4 \\
\hline Lectures & 2 & 13.3 \\
\hline Podcasts/pedagogical games & 2 & 13.3 \\
\hline Presential classes & 2 & 13.3 \\
\hline Visits to schools & 1 & 6.7 \\
\hline TOTAL & 15 & 100 \\
\hline
\end{tabular}

Source: Prepared by the authors (2022).

It is known that practices are essential in the initial training of any educational professional. But despite this limitation imposed by remote teaching, according to the students, the discipline allowed the development and/or improvement of classroom skills, such as creativity, enthusiasm, confidence, reflection, critical thinking, working in groups, organization of time, communication, and writing, as is clear in the speech of three students:

Criticality, better interpretation of texts, working in groups (E1).

The course helped me to improve my classroom skills and also to develop new skills, since I was paying for two internship discipline in the same semester that I paid for Practicum IV, which facilitated my regency. About the role of the teacher, types of methodologies, didactic tools that can be used, as well as exercising empathy and making the classroom a more pleasant place in these difficult times, among other skills (E2).

A better understanding about the pedagogical practices and resources we will use as future teachers (E3).

If they had to teach science classes in elementary school, the students reported that they would use different methodologies and teaching resources, as is clear in the speech of five students:

Use of technological tools, concept maps, interactive games, among several others, in order to make the classes more attractive, and facilitate the content so that through curiosity, and interaction learning is more efficient (E1);

One of the teaching resources would be videos and writing to discuss and understand the students, because besides teaching, you have to learn a little. And a very important point that I learned was the issue of teaching in a way that students would learn and take to life and not that content that you study today and forget tomorrow. So, considering this, classroom practice, conversation, attention to students will always be important (I2);

I would use all that is within the reach of the school and students. If there is a laboratory room I will want to use, the possibility of building vegetable gardens and gardens I will want to use, and if there is only a board, books and pencils I will use. But I will always try to get away from the usual methodology that tires and demotivates the student. I will also try to figure out the best way my students can learn and I will approach it that way. I want to be able to use all the methods that I know. From books, games, field trips, visiting different places or inside the school, to observing the sky. I want my student to be receiving and retaining knowledge (E3);

Overhead projectors, to pass videos and slides with pictures and content, as well as movies and other activities, I would also use simple resources like a board and an eraser to be able to conduct my classes. Of course, the activities would be more challenging than just solving questions from a book. I believe that simple field research would fix the subject and would also be a different way to gain knowledge (E4);

I would use the computer with games, plenty of images and illustrative videos for good visualization, as well as practical classes through research so that the student can develop building their own knowledge with my help as a teacher (E5). 
These statements are important, because they show that when the teacher uses a diversity of methodologies, consequently, the capacity for reading, interpretation and learning is expanded, which are fundamental to expand new knowledge, including the skills to use DTIC (Feitosa et al., 2020).

However, the highest mentions about the didactic methods that students would use if they had to teach Science classes for elementary school were DTIC, with $36.7 \%(n=18)$ of the answers (Table 3$)$.

Table 3: Categories of answers obtained about the mentions of didactic-pedagogical methods to be used in science classes in elementary school.

\begin{tabular}{l|c|c}
\hline \multicolumn{1}{c|}{ Categories } & $\mathbf{N}^{\circ}$ & \% \\
\hline DTIC/videos/films/images/slides/internet & 18 & 36.7 \\
Practical classes/field trips/laboratories/gardens/gardens & 9 & 18.3 \\
Pedagogical games/interactive/online/applications & 7 & 14.3 \\
Production of didactic material/recycled material/student reality/posters/mock-ups & 6 & 12.3 \\
Lectures/seminars/workshops & 4 & 8.2 \\
Books/chart & 3 & 6.2 \\
Conceptual/mental maps & 2 & 4.0 \\
\hline \multicolumn{1}{c}{ TOTAL } & 49 & 100 \\
\hline
\end{tabular}

Source: Prepared by the authors (2022).

In the teaching of Science and Biology, DTIC is necessary, and is even mentioned in the speech of one of the students, who says he would use it in his classes, because for him, DTIC:

have proven to be an important didactic resource for teaching biology, because besides motivating, they instigate students to seek information to build their knowledge (II).

Thus, the DTIC played an important educational role in this period of the COVID-19 pandemic, in which it was necessary to work and study remotely (Costa et al., 2020).

Although we have observed that the profile of students in Elementary and High School has changed a lot, mainly due to the advent of new technologies, we have no doubt that it is increasingly necessary reformulations in pedagogical practice, in such a way that students' attention turns to Science, Technology \& Innovation (S,T\&I), awakening in them the curiosity and willingness to learn more and more.

However, we cannot fail to mention that the student's reality is also important and necessary and should be taken into consideration, including in Science and Biology teaching. About this, a student says that:

I liked an approach that I read in an article, that the person asked the students what animals they had at home and from there made the lesson. In other words, it brought the students into the lesson (E1).

It is also worth noting that students learn significantly by constructing their knowledge when they bring the learning of science and biology closer to their social context. In this way, the teacher's practice must be valued, considering his or her role as a "builder of knowledge", and not as a mere instructor who transmits the knowledge produced by others.

According to Paulo Freire's liberating pedagogy, school activity should be based on discussions of social and political issues and on actions concerning the immediate social reality (Menezes, 2001). Reality plays a fundamental role, since it is both the mediator and the content to be learned. Through the perception of the world, concepts are built and meanings are 
attributed to reality, which, in a cycle, will later influence readings and re-significations (Freire, 1987).

In the students' opinion, Pedagogical Practice is very important for the training and performance of Science and Biology teachers in Basic Education. In their view, the discipline allowed them to learn concepts and resources that are essential for good teaching practice, according to the words of three students:

It is very important, because it is through the classes of this discipline that we learn most of the methodologies and tools that we can use in our profession (I1);

It is important because through this discipline we learn concepts and practices that are essential for teaching. It is important because through this discipline we learn concepts and practices that are essential for teaching. Little by little, we get to know our students better and better, and propose simpler and more meaningful teaching-learning methods (E2);

In my opinion, pedagogical subjects are the most important when it comes to forming good teachers (E3).

As future teachers, the students consider the subjects covered in the discipline Pedagogical Practice to be very relevant, as it allows them to "open their minds", train educators, build and improve their knowledge about teaching, helping in the day-to-day practice of the classroom, as was evident in their speeches.

Despite the importance given to initial training, students also consider continuing education important, as it allows the improvement of the knowledge necessary for the teacher's activity, ensuring an effective teaching performance and promoting new learning. However, for continuing education not to be at the mercy of quantitative evaluation processes, it is important that the university implement an internal and systematic system of evaluation of the training paths (Diniz-Pereira, Flores \& Fernandes, 2021).

\section{Final Considerations}

The opinion of Biological Sciences undergraduate students from a public Brazilian university about the discipline Pedagogical Practice, developed in the remote format, during the pandemic of COVID-19, revealed, among other information, the decrease in the quality of the discipline taught remotely; problems and difficulties in accessing the internet, with slow or unstable connections; the absence of face-to-face practical classes that makes it impossible to contact and socialize with professors and classmates, and the overload and difficult concentration during this period.

On the other hand, most students said that reading and presenting scientific articles during the remote classes was the methodology that most allowed them to learn contents in a meaningful way, which is important so that they can know and learn subjects related to Science and Biology in a scientific way that can be contextualized with their reality.

It is essential to point out that almost all students understand hands-on activities, as well as videos, movies and other audiovisual resources as important and fundamental to pedagogical practice. However, it is understood that such activities and resources do not necessarily need to be used only in online classes, but can also be used in face-to-face teaching.

With this research, it is expected that other studies about remote learning in undergraduate courses, especially in Biological Sciences, may address new teaching methodologies and pedagogical practices developed in different learning contexts. This helps to understand other difficulties present in the formation of teachers for science teaching.

Based on the students' reports, it is expected that this study may contribute to expand the production of knowledge in the area, mainly regarding teacher education, by proposing new reflections about pedagogical practices and teaching methodologies with Brazilian university students. 


\section{References}

Bardin, L. (2011). Análise de conteúdo. Traduzido por Luís Antero Reto, Augusto Pinheiro. Edições 70

Bogdan, R. I., \& Biklen, E. (2010). Investigação qualitativa em educação. Atlas.

Brasil. (2020). Ministério da Educação. Portaria $n^{\circ} 343$, de 17 de março de 2020. Dispõe sobre a substituição das aulas presenciais por aulas em meios digitais enquanto durar a situação de pandemia do Novo Coronavírus - COVID-19. DOU n 53, 18.03.2020, Seção 1, p.39, 2020. https://www.in.gov.br/en/web/dou/-/portaria-n-343-de-17-de-marco-de-2020-248564376.

Brasil. (2016). Resolução $n^{\circ}$ 510, de 07 de abril de 2016. Diz respeito sobre as normas aplicáveis a pesquisas em Ciências Humanas e Sociais cujos procedimentos metodológicos envolvam a utilização de dados diretamente obtidos com os participantes ou de informações identificáveis ou que possam acarretar riscos maiores do que os existentes na vida cotidiana, na forma definida nesta Resolução. Brasília: Conselho Nacional de Saúde.

Brasil. (2012). Resolução $n^{\circ} 466$, de 12 de dezembro de 2012. Diz respeito sobre as diretrizes e normas regulamentadoras de pesquisas envolvendo seres humanos. Brasília: Conselho Nacional de Saúde.

Brasil. (1939). Decreto-lei $n^{\circ} 1.190$, de 4 de abril de 1939. Dá organização à Faculdade Nacional de Filosofia. Diário Oficial da União - Seção 1 - 6/4/1939, Página 7929 (Publicação Original).

Castaman, A. S., \& Rodrigues, R. A. (2020). Distance Education in the COVID crisis - 19: an experience report. Research, Society and Development, 9(6), e180963699. https://doi.org/10.33448/rsd-v9i6.3699

Costa, V. S., Costa, F. G., Cipriano, T. H. S., \& Castro, I. F. A. (2020). As Tecnologias da Informação e Comunicação (TICs) como ferramentas para o ensino de genética em aulas não presenciais. In Anais...VII Congresso Internacional das Licenciaturas - COINTER PDVL.

Diniz-Pereira, J. E., Flores, M. J. B. P., \& Fernandes, F. S. (2021). Princípios gerais para a reforma dos cursos de licenciatura no Brasil. Interfaces da Educação, 12(34), 589-614. http://dx.doi.org/10.26514/inter.v12i34.5384

Dosea, G. S., Santos do Rosário, R. W., Andrade Silva, E., Reis Firmino, L., \& dos Santos Oliveira, A. M. (2020). Métodos ativos de aprendizagem no ensino online: a opinião de universitários durante a pandemia de COVID-19. Educação, 10(1), 137-148. https://doi.org/10.17564/2316-3828.2020v10n1p137-148

Emanuelli, G. B. (2011). Atração e refração na educação à distância: constatações sobre o isolacionismo e a evasão do aluno. Revista GUAL, 4(2), 205-218. https://doi.org/10.5007/1983-4535.2011v4n2p205.

Fonseca, J. J. S. (2002). Metodologia da pesquisa científica. UEC.

Feitosa, M. C., Moura, P. S., Ramos, M. S. F., \& Lavor, O. P. (2020). Ensino Remoto: O que Pensam os Alunos e Professores? In Anais...V Congresso sobre Tecnologias na Educação (CTRL + E 2020). 1-9. https://doi.org/10.5753/ctrle.2020.11383

Freire, P. (1987). Pedagogia do oprimido. (17a ed.), Paz e Terra.

Kafer, G. A., Wyrepkowski, C. C., Bisognin, E., \& Pigatto, A. G. S. (2017). Formação de professores de Química: uma análise de manuscritos. In Anais...37 Encontro de Debates sobre o Ensino de Química. FURG, 1-8.

Langin, K. (2021). On the verge of a breakdown. Report highlights women academics pandemic challenges. Science. https://doi.org/10.1126/science.caredit.abh4450.

Menezes, J. B. F. (2021). Práticas de avaliação da aprendizagem em tempos de ensino remoto. Revista de Instrumentos, Modelos e Políticas em Avaliação Educacional, 2(1), e021004. https://doi.org/10.51281/impa.e021004

Menezes, E. T. (2001). Verbete pedagogia libertadora. Dicionário Interativo da Educação Brasileira - EducaBrasil. São Paulo: Midiamix Editora. Recuperado de: https://www.educabrasil.com.br/pedagogia-libertadora/.

Minayo, M. C. S. (Org.). (2001). Pesquisa Social: teoria, método e criatividade. (19a ed.) Vozes.

Moraes, R. (1999). Análise de conteúdo. Revista Educação, 22(37), 7-32.

Moreira, M. A. (2012). Al final, qué es aprendizaje significativo? Qurriculum: revista de teoría, investigación y práctica educativa, (25), 29-56.

Oliveira, S. L. (2002). Tratado da Metodologia Científica: projetos de pesquisas, TGI, TCC, monografias, dissertações e teses. Pioneira Thomson Learning.

Roig-Vila, R., Urrea-Solano, M., \& Merma-Molina, G. (2021). La comunicación en el aula universitaria en el contexto del COVID-19 a partir de la videoconferencia con Google Meet. RIED. Revista Iberoamericana de Educación a Distancia, 24(1), 197-220. http://dx.doi.org/10.5944/ried.24.1.27519

Santos, L. M. A., Silva, M. F., Minuzi, N. A., \& Saidelles, T. (2020). Desafios e oportunidades para a mediação pedagógica em tempos de Covid-19: um olhar com base nas competências digitais. Redin, FACCAT, 9(1), 36-47.

Silva, A. E. A. (2021). O uso do Google Classroom como recurso pedagógico em tempos de COVID-19: uma prática de ensino na Escola Maria Vieira de Pinho, em Ipaporanga-CE. Revista Nova Paideia - Revista Interdisciplinar em Educação e Pesquisa, 2(2), 25-38. http://dx.doi.org/10.36732/riep.v2i2.45.

Weber, A. F., \& Pérsigo, P. M. (2017). Pesquisa de opinião pública: princípios e exercícios. FACOS-UFSM. 